\title{
Balancing Junior College Instruction with Library Support'
}

Miss Clay is librarian, Northeast Junior College of Louisiana State University, Monroe.

$\mathrm{T}$ He Southern states have a reason to 1 have pride in their development in the junior college field. In 1906 Kentucky was the first state in the country to formulate standards for accrediting junior colleges. ${ }^{2}$ In $1946-47$ the southern region, as represented by Texas, had the largest state enrolment in private colleges, the largest increase in public junior college enrolment, and the largest number of new colleges. ${ }^{3}$ Mississippi, with her planned statewide system of junior colleges, matched California in providing junior college advantages to each 96,000 of the population in $1940 .^{4}$

Among all regional groups the Southern Association of Colleges and Secondary Schools has had the distinction of containing the largest number of regionally accredited junior colleges. In the official report of the American Association of Junior Colleges in I947 only 170 junior colleges were accredited by one of the five regional groups, with approximately 70 of these being in the South. ${ }^{5}$ Wheeler has called attention to the fact that the Southern Association has at times led the country in understanding, high purpose, and requirements. ${ }^{6}$ Although he

\footnotetext{
1 Based on a paper read at the meeting of the Southern Association of Junior Colleges, Louisville, Ky., Dec. I, 1947.

2 American Council on Education. American Junior Colleges. Washington, The Council, 1940, p. $4 \mathrm{r}$.

3 American Association of Junior Colleges. Junior College Directory, 1947. Washington, A.A.J.C., 1947, p. 33 .

American Council on Education. Op. cit., p. 29. p. 36 .
}

was referring to school library training and practice, the comment is a tribute. Whether it is held that junior college education is an extension of secondary education or that it is a type of higher education, it is generally agreed that junior college libraries need to provide facilities superior to those in the average high school. A first step for junior college librarians, therefore, in studying their role is to re-examine present standards.

As chairman of the Junior College Libraries Section of A.C.R.L., the writer initiated a study of regional and state library standards in 1946-47. Reports were received from five regions and California. The evidence in these reports indicates that standards for junior college libraries need to be raised in other official accreditation regions and in California. Since California lies outside of the official accreditation associations, it had no formal standards except for the general requirements for colleges participating in state-aid funds. Summaries of the regional reports and other activities of the Junior College Libraries Section appeared in a mimeographed publication distributed last year. ${ }^{7}$ The full report of the section's committee for the southern region is also available. ${ }^{8}$ The data used in the

${ }^{6}$ Wheeler, Joseph L. Progress and Problems in Li. brarianship. New York, Carnegie Corporation, 1946,

p. ${ }^{\mathrm{I}}$ A.C.R.L. Junior College Section. "Progress Report," v. I, r $946-47$; ed. by Mary H. Clay, chairman. Monroe, La., P.O. Box 693, The Section, 1947.

${ }^{8}$ A.C.R.L. Junior College Section, Southern Regional Committee on Standards, 1946-47. "Suggestions for Revision in the Junior College Standards for the Southern Association of Colleges;" ed. by Lola R. Thompson, chairman. [Stephenville, Tex., r947.] 
following discussion were obtained by questionnaire to the $6 \mathrm{I}$ junior college librarians in colleges approved by the Southern Association. Forty-five replies were received, but only 35 were usable.

\section{Staff Standards and Service Loads}

Requirements for library staff may be examined on the basis of present standards: "The librarian should be a full-time library employee, have a degree in library science, and have faculty rank." With expansion of curricula additional teachers are employed to handle the extra load. In the present Southern standards no mention is made of library staff expansion to meet a growing service load in a college library. In the American Library Association's publication School Libraries for Today and Tomorrow: Functions and Standards, issued in 1945 , is the following statement: "A completely successful library requires a budget adequate to provide a staff of librarians and clerical assistants sufficient in number to administer the library and provide consulting and advisory services to the students and faculty members." While the exact number needed in a specific junior college will depend on a variety of local conditions, the implication in the present standard that one librarian is always adequate should be changed to provide for staff expansion to match other college growth. A study of college catalogs of the Southern accredited group reveals the presence of one private junior college with an enrolment of approximately 350 which has two full-time professionally-trained librarians and a third staff member with a college degree.

In 1930 the group of junior college librarians in the American Library Association recommended the following in regard to personnel of library staff for junior colleges of different sizes : ${ }^{9}$

\footnotetext{
- Stone, Ermine. The Junior College Library. Chi cago, A.L.A., 1932.
}

x. For the library of 500 students or less it is recommended that there should be two professional librarians, supplemented by student help and clerical assistance.

In the Southern colleges within this size range from which data were obtained it was found that only one college met this recommendation in $1946-47$.

2. For the library of 500 to rooo students there should be a librarian, three professional assistants, and clerical assistance.

Data from questionnaires reveal that no colleges under 1000 in enrolment in the group provide a library staff of the recommended size. One college has two and onehalf professional assistants and another has two professional assistants and one subprofessional. In the few Southern colleges with enrolments over 1000 there are two with professional staffs of three and two others with staff members of clerical or subprofessional grade. The standards provide for a sixth member of the professional staff for enrolments beyond 1500 . But in each size group the staffs provided are smaller than those recommended for colleges on the basis of their enrolment and number of faculty members. In $1936-37$ the group of colleges studied enrolled 10,334 students, or an average of 313 for the colleges responding to this question. In $1946-47$ the same institutions enrolled $2 \mathrm{I}, 580$, with an average enrolment of 654 . To take care of these enrolment increases, which have more than doubled, the average college in the group increased the faculty from eighteen in $1936-37$ to thirty-four in 1946 47. These larger faculties also add to the service load of the library staffs. How do additions to the library staff compare to other increases? At the end of the comparative period professional assistants held positions in only eight colleges, or less than one-fourth of the group. The median size of the library staff remains at one. Thus, nothing has been done to meet the increased 
load on the libraries in most cases. Moreover, in connection with student help provided, libraries have lost in the period since 1936-37, the N.Y.A. helpers and the adult W.P.A. workers, both formerly supplied by government funds without cost to the college. To add to the problem, a few colleges have added classroom duties to the already burdened library staff. The returns on the questionnaire show that in seven of the colleges the librarian is not permitted to select student assistants.

\section{Salaries and Increases}

It is understood that the Commission on Secondary Education of the Southern Association has ruled that, for purposes of salary scales and ranking, librarians holding the B.S. in Library Science, or B.L.S., representing a fifth year of professional study beyond the first A.B. degree, should have the same recognition as faculty members with the master's degree in other subject fields. Of the twenty-four replies concerning the degree to which the librarian's salary had been increased as compared to that of other faculty members of equivalent training and experience, seven or nearly onethird indicated that their salary increases had been less than that of the other faculty members. In answer to the question on the total increase in the librarian's monthly salary over the decade, none received more of an increase than the librarian who started at $\$ 60.00$ and at the end of sixteen years received $\$ 187.50$. One Texas librarian replied that she had received an increase of IoO per cent. As she gave no figure, her salary increase could not be included in these summaries. Eighteen of the salary increases were less than $\$ 65.00$ a month for the entire ten years. Three Texas colleges raised their librarians' salaries $\$ 100.00$ and over per month, but not in excess of the record \$127.50 for another state. The average raise for those responding amounted to $\$ 53.43$ for ten years. The average monthly increase in one year thus comes to \$5.34. According to a Nov. 22, 1947, release from the U. S. Bureau of Labor Statistics, the rise in food prices has brought the food index for September 1947 to 203.5 per cent of the $1935-39$ average. $^{10}$

These conditions are directly responsible for the considerable turnover of staffs in junior college libraries. Five of the colleges changed librarians three times; two others changed four times. There are many single resignations in the librarianships and assistantships. Junior college librarians are finding that senior colleges, public libraries, special libraries, and even high school libraries are offering more attractive salaries. For example, the Texas State Department of Education indicates that the following salaries are being actually received this year : ${ }^{11}$

San Antonio-5 high schools paying $\$ 400$ per month.

Houston-8 high schools paying between $\$ 3000$ and approximately $\$ 4000$ per year.

Dallas-4 high schools paying $\$ 3000$ and above, and I paying $\$ 4000$.

\section{Inadequacy of Specified Number of Vol- umes and Per Capita Book Expenditures}

In regard to holdings, which we also believe need reconsideration, the present standards require that "the small junior college should have 4000 volumes." While junior college libraries do not need the quantity of volumes that senior colleges do for research, the cost of keeping the collection in good condition by replacement of worn copies, binding of reference periodicals, and purchasing the important new books needed for the various courses and for cultural reading

${ }^{10}$ The Shreveport Times, Nov. 23, 1947, p. 22, "Price Index Higher."

11 Source: Letter from Mattie Ruth Moore, director of school libraries, Texas State Department of Education, on Nov. 24, 1947. 
is a significant item in a college budget. While the present requirement of $\$ 2.50$ per capita for expenditures for books, periodicals and binding has served a useful purpose in building the initial book collections in Southern libraries, such a quantitative yardstick will not measure the adequacy of a library for the educational program of a particular institution. Dr. Doak S. Campbell, president, Southern Association of Colleges in 1947 and a former secretary of the American Association of Junior Colleges for sixteen years, has commented on the proper basis for determining the size of a library as follows:

The requirement of a given number of books per student enrolled is open to serious question, whether the requirement be on a flat scale of five books per student or on a graduated scale. The chief factor in determining the size of the library should be the curriculum. The size of the student body becomes a factor only as enrolments in spe. cific courses require more duplicate copies of the books necessary for such courses. ${ }^{12}$

\section{Curriculum and the Library}

Through the cooperation of Dr. James Reynolds and three graduate students in the junior college field, data were collected for the same group of colleges under consideration. College catalogs available at Peabody were analyzed. Comparable information for a representative group of sixteen colleges reveals the following trends in the curricula for the decade from 1936-37 through 1946-47 :

Percentage

Total number of curricular offer-

ings by group ror $16 \mathrm{r}$

59.4

12 Campbell, Doak S. Libraries in the Accredited High Schools of the Association of Colleges and Secondary Schools of the Southern States: A Report of the Status of High School Libraries with Respect to the New Library Standards of the Association. Nash. ville, Tenn., George Peabody College, Development Surveys and Field Studies, 1930, p. 5.
Total number dif-

ferent semester hours offered in group $\quad 3046 \quad 5056$

Average number hours per institution $190 \quad 316$

66.3

These figures indicate that there has been a decided increase in course offerings. From the questionnaires it was learned that only one-fourth of the librarians are members of curriculum committees. In fact, in onethird of the colleges no such committees have been established. In nearly one-half of the colleges the librarians reported that new courses were added to the curricula in colleges which have inadequate library resources. It is obvious that $\$ \mathbf{2 . 5 0}$ per capita cannot meet increased needs of new courses. We do not argue for a narrow curriculum if the college has financial resources to support broad library purchases.

\section{Other Factors}

Among other recent factors which have the library side of the instructional scales calling for increases in library budgets are the following:

I. "Operating costs of libraries have increased 50 per cent since 1940," according to Carl H. Milam, former Executive Secretary of the American Library Association. ${ }^{13}$ "Such a reduction in buying power of libraries would be serious at any time. It is tragic in this period when the U.S. and the world need a great improvement and expansion of the agencies of communication, information, and education." Twelve librarians, or approximately one-third of the group, responding in time for tabulation, indicated that teachers complained that book funds are now insufficient to meet the needs of their departments. Several noted that most departments reported that adequate funds were not available.

2. On the national level the percentage of special students in junior college has increased

13 A.L.A. press release, Oct. 21, 1947, on American Library Association's Annual Report, 1946-47. 
from 15 per cent in 1937 to 47.6 per cent in 1947. This has resulted in requests for evening hours of opening, special reserve book regulations, greater duplication of titles, and more demands on the staff.

3. The introduction of audio-visual aids in instruction has created demands upon libraries to stock and service these expensive, but important tools. Use of these aids during the war has accelerated the spread of their adoption in colleges.

4. The rapid development of terminal and semiprofessional training in the junior colleges call for book and periodical purchases of a different type than those needed in general and preprofessional work of the first two years, thereby adding to the cost of proper library development.

5. Instead of temporary makeshift solutions of problems created by the large veteran enrolment in junior colleges, prominent educational leaders suggest permanent programs in these institutions. In evaluating the possible expansion in junior college education, President J. B. Conant of Harvard wrote, "Here we have the most exciting area of educational activity and one that holds great promise for the future." 14 President T. S. Painter, of the University of Texas, stated recently that in selecting the faculty, he will concentrate on graduate and upper level faculty because the junior colleges are taking over more and more of education at the lower college level. ${ }^{15}$

6. Adequate library budgets are needed to provide materials and services to meet the changed methods of teaching and rapid expansion in fields of knowledge which make "the whole library the textbook" for the modern student, according to President Sproul of California. ${ }^{16}$ Pioneer work in integration of the library and instructional programs has been done by a junior collegeStephens College of Missouri. Dean B.

14 Conant, J. B. Public Education and the Structure of American Society. New York, Columbia University, 1946 , p. 39 .

Texas Junior College News Letter, v. 4, Nov. 6, 947 , p. 3-4.

or Alanche P. An Estimate of Standards Lee, 1937, p. 3 .
Lamar Johnson reports a library staff budget last year of approximately $\$ 30,000$. While that figure may be unattainable for most junior college libraries now, it is indicative of the cost of adequate library service for the educational program of one particular junior college. Former President Wood of Stephens had a broad vision of the educational possibilities of his library and backed up his vision with budgetary support. "Satisfactory school or college library service is dependent upon adequate financial resources. The school (or college) administrator cannot expect maximum results with minimum expenditures." ${ }^{17}$

\section{Summary}

The evidence available shows that the support of the junior college libraries has not kept pace with the growth in enrolments, number of faculty members and course offerings. Demands upon the college library service can only be way below par. Costs for personnel, books, supplies and equipment continue to rise, and the only way out is increased budgets. ${ }^{18}$ As presidents and deans and boards of trustees recognize this situation, which has been growing progressively worse in most cases during the decade from 1937 through 1947 , active steps will be essential to balance the financial support of the library to match the much heavier load the junior college library is now carrying. Administrators wanting truly adequate library service will need to add dollars on the library side of the budget in proportion to the growing significance of the library in junior college instruction.

17 School Libraries for Today and Tomorrow: Func. tions and Standards. Chicago, A.L.A., r945.

is Since this paper was read in December 1947, the American Library Association Council, on Jan. 31, 1948 , revised the Minimum Library Standards for 1948. The minimum salary expenditure per unit of service load (for the first 1000 units at the junior college level) was raised from $\$ 8$ to $\$ 11$ in recognition of the "failure of library salaries to keep up with living costs." The service load is figured at one unit for each regular junior college student and five for each faculty mem. ber. A.L.A. Bulletin, 42:104-07, March 1948. 